ARTICLE

Received 1 Jun 2012 | Accepted 20 Dec 2012 | Published 29 Jan 2013

DOI: $10.1038 /$ ncomms 2410

\title{
Constraining timescales of focused magmatic accretion and extension in the Afar crust using lava geochronology
}

\author{
David J. Ferguson ${ }^{1, \dagger}$, Andrew T. Calvert ${ }^{2}$, David M. Pyle${ }^{1}$, Jon D. Blundy ${ }^{3}$, Gezahegn Yirgu ${ }^{4}$ \\ \& Tim J. Wright ${ }^{5}$
}

As continental rift zones mature the tectonic and volcanic processes associated with crustal extension become confined to narrow magmatic rift zones, reminiscent of oceanic spreading ridges. The formation of these rift zones and the development of ocean-ridge type topography is a significant milestone in rift evolution as it signifies the localization of crustal extension and rift-related volcanism. Here we show that lavas, which erupted since $\sim 200$ ka along part of the on-land Red Sea rift system in Afar, Ethiopia, have a consistent age-progression from the rift axis outwards, indicating that axial dyke intrusion has been the primary mechanism of segment growth and that focused magmatic accretion and extension in the crust have remained stable here over this period. Our results suggest that as this rift segment has formed, in thinned and intruded continental crust, the time-averaged surface opening rate has closely approximated the total extension rate between Africa and Arabia.

\footnotetext{
${ }^{1}$ Department of Earth Sciences, University of Oxford, South Parks Road, Oxford OX1 3AN, UK. ${ }^{2}$ US Geological Survey, 345 Middlefield Road, Menlo Park, California 94025, USA. ${ }^{3}$ Department of Earth Sciences, University of Bristol, Wills Memorial Building, Queens Road, Bristol BS8 1RJ, UK. ${ }^{4}$ Department of Earth Sciences, University of Addis Ababa, P.O. Box 1176, Addis Ababa, Ethiopia. ${ }^{5}$ School of Earth and Environment, University of Leeds, Leeds LS2 9JT, UK. $\dagger$ Present address: Lamont-Doherty Earth Observatory, Columbia University, P.O. Box 1000, 61 Route 9W, Palisades, New York 10964-1000, USA.

Correspondence and requests for materials should be addressed to D.J.F. (email: davef@ldeo.columbia.edu).
} 
n Afar, Ethiopia, late-stage continental break-up is characterized by the formation of en-echelon magmatic rift zones (Fig. 1), representing focused zones of dyke intrusion, volcanism and faulting ${ }^{1}$. At crustal levels the magmatic and tectonic process operating at these segments closely resemble those observed at slow-spreading ocean ridges ${ }^{2-5}$ and axial dyke intrusions appears to have a key role in accommodating extension $^{4}$ and creating characteristic ridge topography ${ }^{6}$. The development of these narrow zones of faulting and magma intrusion signifies an important stage of rift evolution, where extensional processes and volcanic accretion become localised ${ }^{1}$ and final stages of crustal thinning may occur before plate rupture and true oceanic spreading ${ }^{7}$. Geodetic studies indicate that in the southern Red Sea all Afro-Arabian extension of $16-20 \mathrm{~mm}$ per year is currently accommodated on-land within Afar $^{8}$ and the limited magnetic data available suggest that the correlated linear magnetic anomalies, characteristic of oceanic rifts, may have begun forming across the axis of these on-land rift systems, indicating long-term focused volcanic accretion ${ }^{9,10}$

A recent phase of active magmatic rifting (2005-2010) along the Dabbahu-Manda Hararo (DMH) Rift Zone in central Afar $\left(\sim 12.4^{\circ} \mathrm{N}, 40.5^{\circ} \mathrm{E}\right.$; Figs 1 and 2$)$ has demonstrated the critical importance of axial dyke intrusions in accommodating crustal extension across magmatic segments 3,4 . Observations of the multiple $(\sim 14)$ dyke intrusions ${ }^{3,11-17}$ and fissure eruptions ${ }^{18}$ during this active phase have shown that in the upper part of the crust, the delivery of melts to the DMH rift zone is currently strongly focused along the rift axis. The overall scale and morphology of this $\sim 15 \times 60 \mathrm{~km}$ magmatic segment is similar to

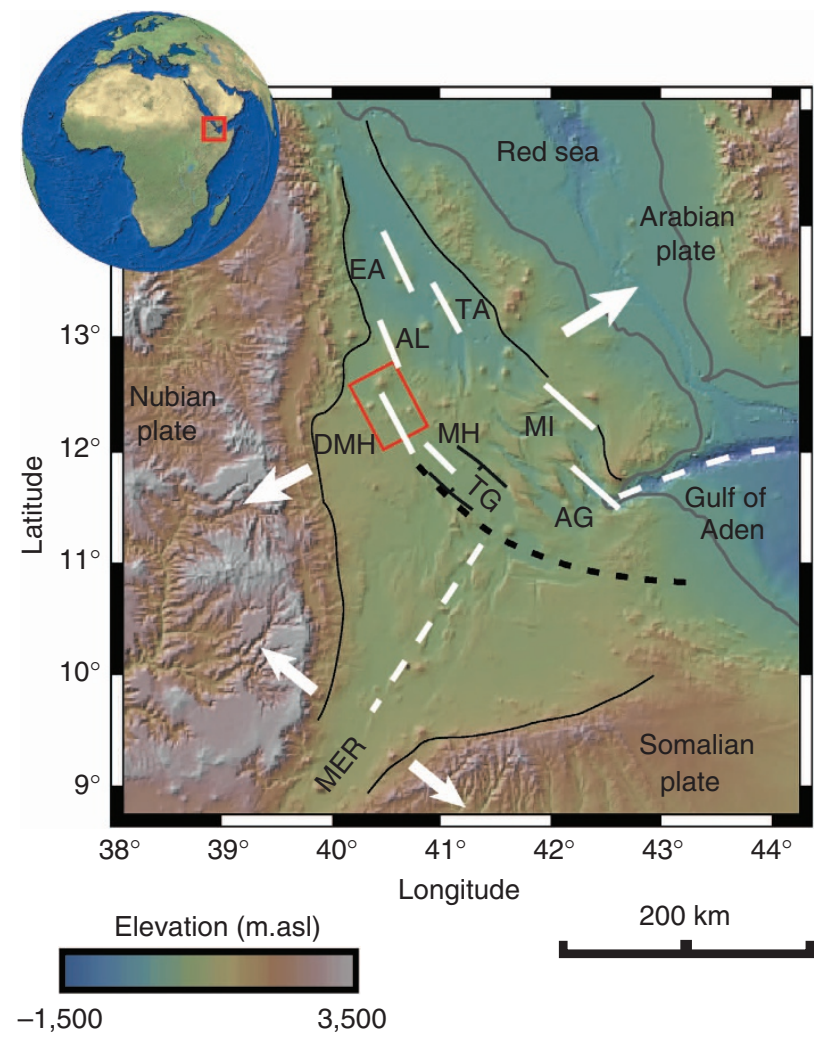

Figure 1 | Topography and tectonics of Afar. Rifting along the on-land sections of the Red Sea and Gulf of Aden rift systems (north of the Main Ethiopian Rift (MER)), have led to formation of segmented zones of focused faulting and magmatism. EA, Erta Ale; TA, Tat Ali; AL, Alayta; DMH,

Dabbahu-Manda Hararo; MH, Manda Hararo; MI, Manda Inakir; AG, AsalGhoubbet; TG, Tendaho Graben. a slow ( $\sim 20 \mathrm{~mm}$ per year) spreading mid-ocean-ridge segment ${ }^{6}$, such as those found along the Mid-Atlantic ridge ${ }^{19,20}$, and the recent episodic rifting activity is similar to that previously observed in Iceland $^{4,2}$. The formation of the DMH segment is broadly constrained by regional K-Ar geochronological studies to have occurred since $\sim 1 \mathrm{Ma}$, following a period of widespread fissural volcanism in Afar between $\sim 1-3 \mathrm{Ma}$ (ref. 22). Measurements of seismic anisotropy shows a preferred orientation for crustal fabrics that trends parallel to the rift axis, implying that the growth of this rift zone has probably been dominated by axially aligned magma intrusion rather than crustal stretching 23

Recent studies here have largely focused on the active volcanic and tectonic phenomena associated with the recent active rifting phase and the contemporary mechanisms of strain accommodation along this part of the on-land Red Sea rift system are becoming increasingly well understood (see review by ref. 3 ). However, the timescales associated with the structural and magmatic processes involved in segment formation remain largely unconstrained and it is unclear to what extent magmatic accretion has been focused along the rift axis during this period. This is partly due to the remoteness of this region, but also the analytical challenges associated with obtaining geochronological data for the young basaltic lavas that form the segment surface. In this paper, we present new ${ }^{40} \mathrm{Ar} /{ }^{39} \mathrm{Ar}$ plateau ages for basaltic lavas from the eastern rift flank that provide constraints on the timing of volcanic-tectonic processes and history of focused melt intrusion.

\section{Results}

${ }^{40} \mathrm{Ar}-{ }^{39} \mathrm{Ar}$ geochronology. Lava samples for geochemical and geochronological analysis were collected from the eastern flank of the DMH segment north of the Ado Ale Volcanic Complex (AVC) (Figs 2a and 4a). Geochronology of low-K basaltic lavas remains analytically challenging, however meaningful age data can be obtained with suitable analytical techniques (Methods). ${ }^{40} \mathrm{Ar}-{ }^{39} \mathrm{Ar}$ step-heating experiments were performed on groundmass separates of eight lavas from the rift flank; 4 of which produced age-spectra suitable for plateau age determinations, while the remaining samples produced disturbed age-spectra unsuitable for a plateau age interpretation, most likely due to the effects of ${ }^{39} \mathrm{Ar}$ recoil during sample irradiation ${ }^{24}$. Age data from the successful step-heating experiments is listed in Table 1 and the age-spectra from the step-heating experiments shown in Fig. 3. These ages range from $\sim 30$ to $200 \mathrm{ka}$ and provide information on recent volcano-tectonic processes during the formation of this segment.

\section{Discussion}

The DMH segment has a well-defined axial graben offset from the rift flanks by fault scarps $30-100 \mathrm{~m}$ high (Fig. 2b). Along the rift axis the graben is disrupted by the volcanic topography associated with the Ado Ale Volcanic complex (AVC), a series of faulted silicic lavas flows/domes on the rift flanks and a basaltic volcano at the rift axis with a summit crater, and at its northern end the Dabbahu volcano, which has been active since at least $\sim 80 \mathrm{ka}$ (refs 25 and (S. Medynski personal communication)). Seismic ${ }^{11-13}$ and geodetic ${ }^{14-17}$ observations of the recent dyking events are consistent with a magma source located in the rift centre below the AVC. This central volcanic region also marks a division in the width and morphology of the axial graben and rift flanks between the southern (graben $\sim 8 \mathrm{~km}$ wide, scarps $\sim 100 \mathrm{~m}$ high, significant flank topography) and northern (graben $\sim 4 \mathrm{~km}$ wide, scarps $\sim 30-50 \mathrm{~m}$ high, smooth flank profile) sectors (Fig. 2b). Morphological evidence shows that the most recent volcanism has 
a

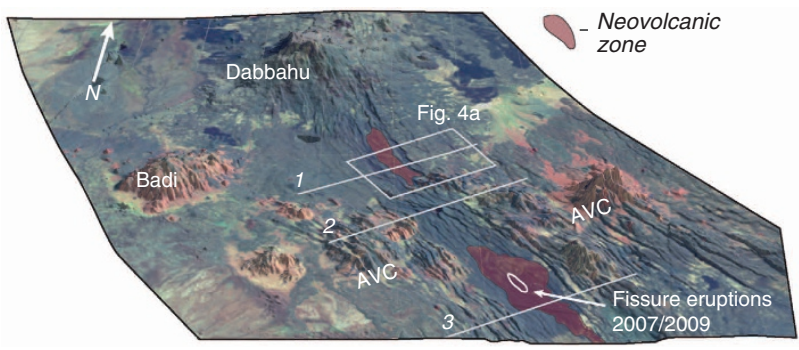

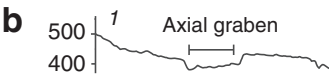

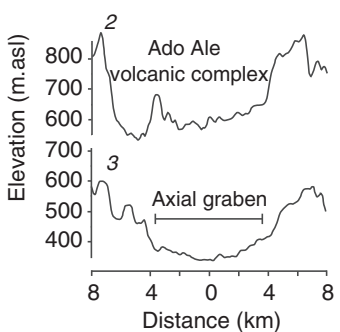

Figure 2 | Topographic map of the DMH magmatic segment. (a) False colour Landsat ETM + image of the DMH rift segment. The $\sim 15 \times 60 \mathrm{~km}$ segment is defined by a zone of closely spaced faulting and recent volcanism. The neovolcanic zone (red area) is recognized from accumulations of recent basaltic lavas (based on flow morphology), which have been concentrated in the axial graben on the northern and southern sides of the Ado Volcanic Complex (AVC). Rhyolitic and trachytic lavas forming parts of the AVC and Badi appear red in colour, basaltic lavas forming the rift floor are dark grey. (b) Across axis topography (lines of sections shown in 2a). Significant variations occur in segment morphology between the southern and northern sectors.

Table 1 | ${ }^{40} \mathrm{Ar} /{ }^{39} \mathrm{Ar}$ ages for basaltic lavas from the DMH segment.

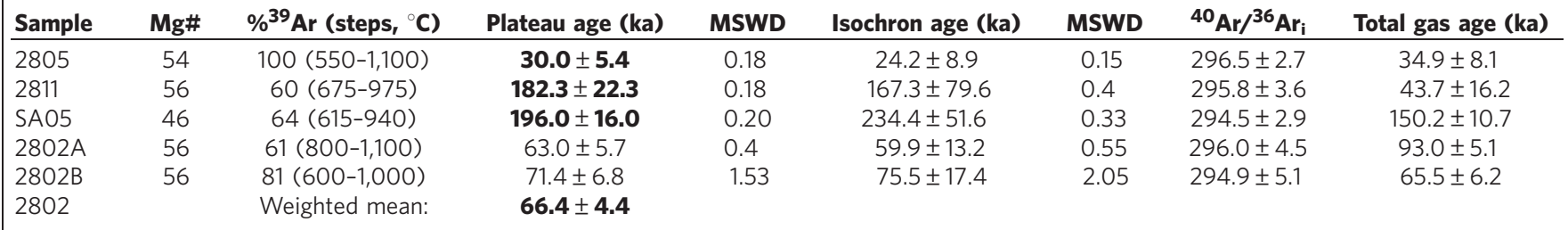

Interpreted ages are in bold. ${ }^{40} \mathrm{Ar} /{ }^{36} \mathrm{Ar}$ is the ratio at intercept and MSWD is the mean squared weighted deviate. All accepted plateaus are defined by at least $60 \%$ of ${ }^{39} \mathrm{Ar}$ released and have a ${ }^{40} \mathrm{Ar} /$ ${ }^{36} \mathrm{Ar}$ value within 2-sigma of the atmospheric value (295.5) on an isochron plot (shown in Supplementary Figs S1-S5). Reported uncertainty incorporates dispersion (square root MSWD) of individual step uncertainties. For sample 2,802 data is given for two separate step-heating experiments. The interpreted age for this sample is a weighted mean of the plateau ages from each analysis. See Methods section for further analytical details and Supplementary information for data plots (Supplementary Figs S1-S5) and full experimental results (Supplementary Tables S1-S5).
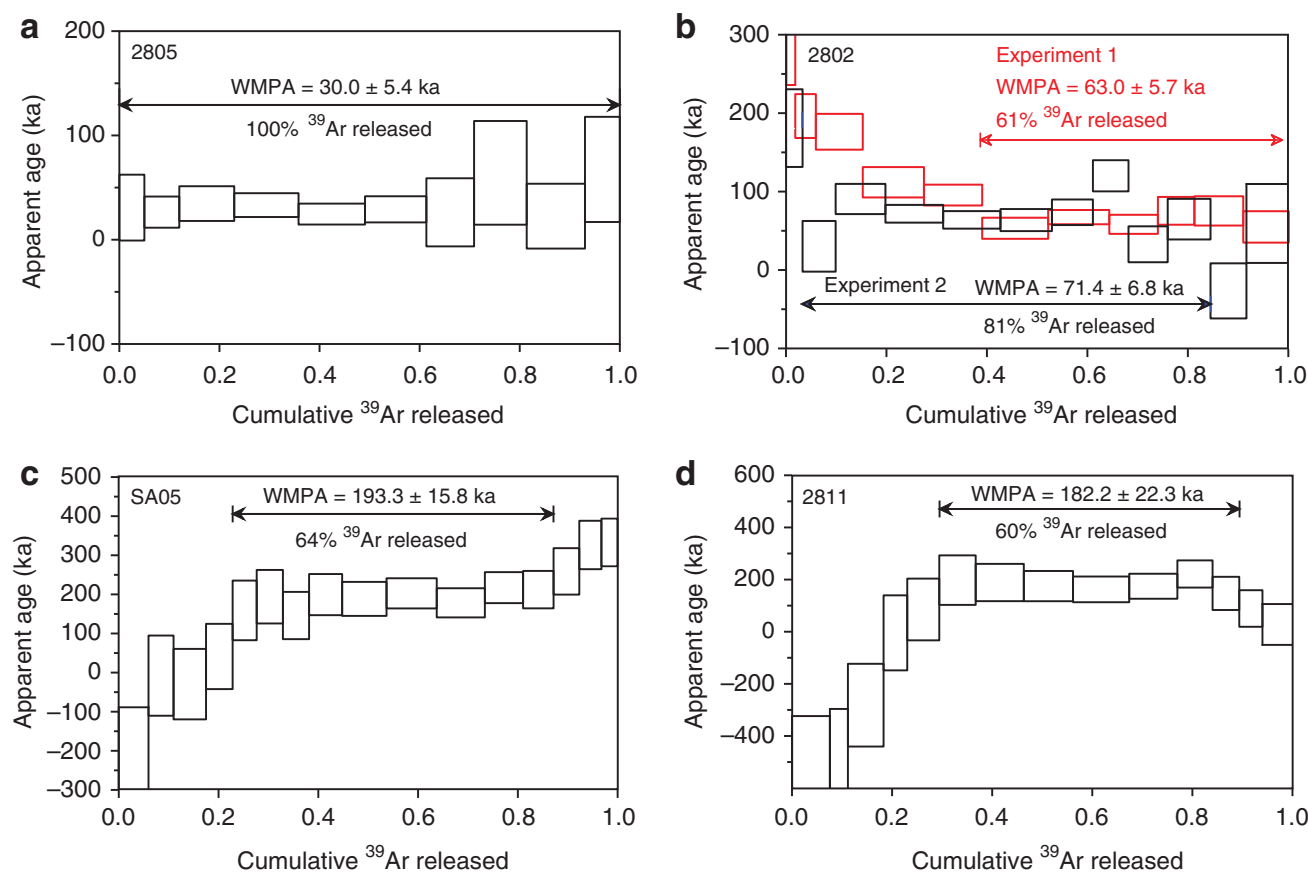

Figure 3 | ${ }^{\mathbf{4 0}} \mathbf{A r -}{ }^{39}$ Ar plateau age diagrams. (a-d) Plots show age-spectra obtained from step-heating experiments versus cumulative ${ }^{39} \mathrm{Ar}$ gas released. Arrows show heating steps used for plateau age determinations. Data from two separate experiments are shown for sample 2,802. The interpreted age for this sample (listed in Table 1) is a weighted mean of the two plateau ages shown. WMPA stands for weighted mean plateau age. See Table 1, Methods and Supplementary information for further details.

been contained within the axial graben, concentrated on the northern and southern sides of the central basaltic edifice (region coloured red in Fig. 2a). These lavas define a $2-3 \mathrm{~km}$ wide neovolcanic zone across the graben centre, which is similar in scale to that found along parts of the mid-Atlantic ridge ${ }^{26}$. Structural evidence from faulting observed during the recent active period 

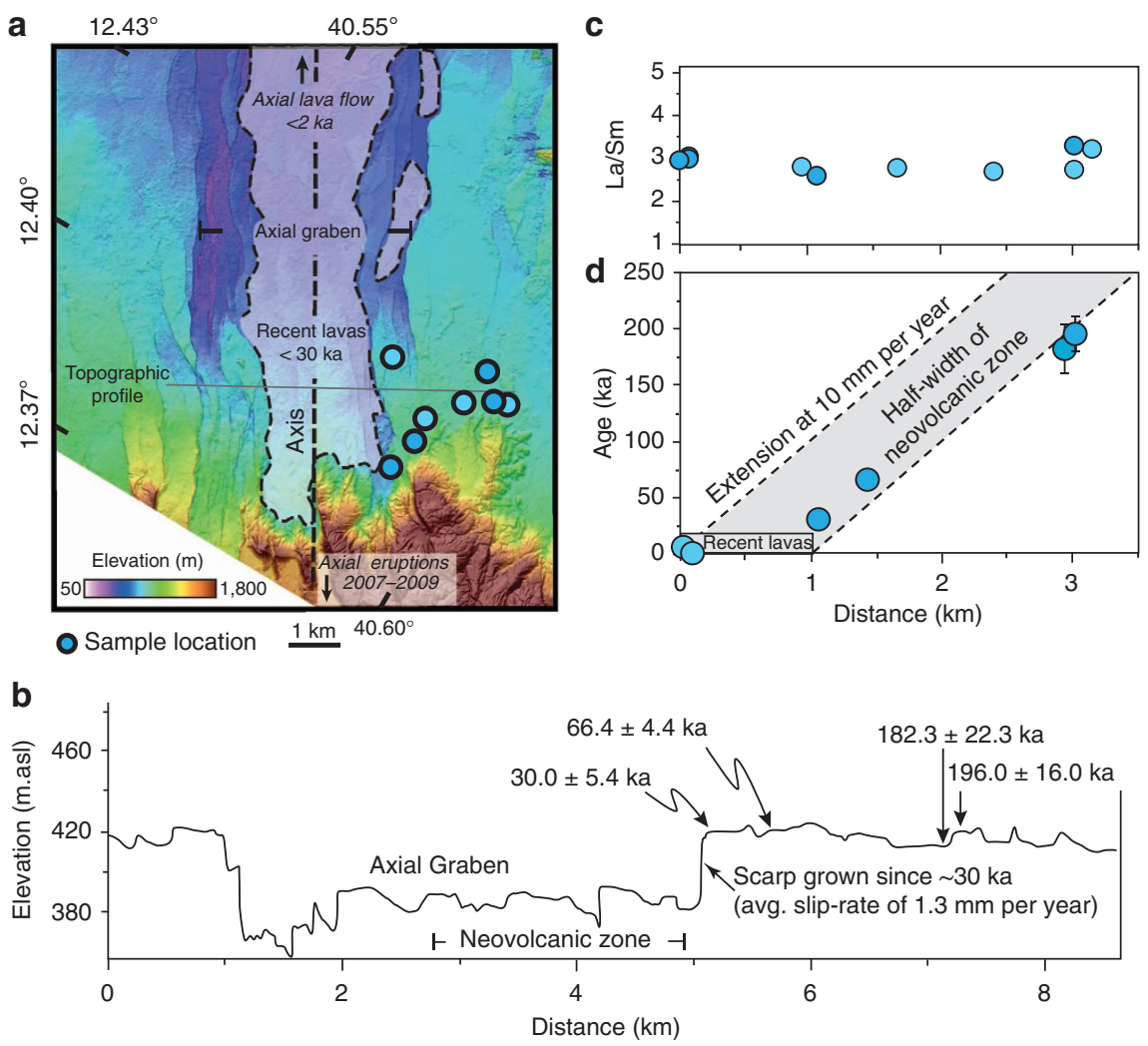

Figure 4 | Age-distribution of lavas across the DMH rift zone. (a) LiDAR topographic map of part of the DMH magmatic segment showing the location of lava samples. The neovolcanic zone is defined by accumulations of recent lavas (shaded white) in the axial graben, which are constrained by our new age data to be $<30 \mathrm{ka}$. Symbols show locations of samples across rift flank (dark blue symbols are those with new ${ }^{40} \mathrm{Ar}-{ }^{39} \mathrm{Ar}$ ages). (b) ${ }^{40} \mathrm{Ar}-{ }^{39} \mathrm{Ar}$ ages from the eastern rift flank projected onto a topographic section. (c) La/Sm versus distance from the rift axis (data from ref. 29 and S. Medynski, personal communication). (d) Age-distance plot for lavas with ${ }^{40} \mathrm{Ar} /{ }^{39} \mathrm{Ar}$ ages ( $>30 \mathrm{ka}$ ) and with known ages from the axial graben. The observed age-distribution can be explained by extension from the centre of the current neovolcanic zone (and location of recent dyke intrusions since 2005) at a velocity close to current Afro-Arabian half rate of $10 \mathrm{~mm}$ per year. 'Zero-age' samples are from axial eruptions in the southern part of the rift between 2007-2009 (ref. 18) and from one flow in the northern section with a cosmogenic ${ }^{3} \mathrm{He}$ exposure age of $<2 \mathrm{ka}$ (S. Medynski, personal communication).

suggests that at the rift surface brittle deformation is largely controlled by dyke intrusion and close links, therefore, exists between magmatism and segment morphology ${ }^{6}$.

One of the flows in our new geochronological data set is offset by the main graben bounding fault scarp (sample 2805 $30.0 \pm 5.4 \mathrm{ka})$ and constrains the growth of this $\sim 40 \mathrm{~m}$ high fault scarp to $<30 \mathrm{ka}$, with a time-averaged slip rate of $\sim 1.3 \mathrm{~mm}$ per year (Fig. 4b). In the northern sector, the growth of this scarp is linked to the formation of the current axial graben, which is shown to be relatively young. Unlike in the southern sector (that is, south of the AVC) large fault scarps are not evident across the northern rift flanks and large-offset faults have either not previously formed here or these have been covered by volcanic infilling. Our new age data provides a maximum age for the present day eastern scarp, however it remains unclear if the growth of this scarp since $\sim 30 \mathrm{ka}$ is the result of increased sliprates or a decrease in volcanic re-surfacing. As recent volcanism has been essentially confined to the axial graben (based on flow morphology, axial eruptions since 2007 (ref. 16)) and one ${ }^{3} \mathrm{He}$ exposure age of $<2 \mathrm{ka}$ (S. Medynski, personal communication; Figs $2 \mathrm{a}$ and $4 \mathrm{a}$ ) our new age data implies that these flows forming the present the neovolcanic zone have a maximum age of $\sim 30 \mathrm{ka}$.

The oldest lavas in our geochronological data set were sampled $\sim 2 \mathrm{~km}$ from the edge of the graben and have ${ }^{40} \mathrm{Ar}-{ }^{39} \mathrm{Ar}$ plateau ages of $196.0 \pm 16.0 \mathrm{ka}$ and $182.3 \pm 22.3 \mathrm{ka}$. A sample between these and the youngest dated flow gives an intermediate age of
$66.4 \pm 4.4 \mathrm{ka}$ (weighted mean of plateau ages from two heating experiments; Fig. 3 and Table 1). Although deformation of these flows by normal faulting currently prevents the reconstruction of individual eruptive systems, and it is, therefore, not possible to precisely locate the paleo-eruptive fissures, potential flow lengths can be estimated from the width of the current neovolcanic zone (assuming axial emplacement). Using this width as proxy for the uncertainty of the paleo-emplacement zone, the observed agedistribution of all lavas with known ages across the rift segment shows a good correlation to a model of emplacement in the axial graben and subsequent transport outwards at a velocity of $\sim 10 \mathrm{~mm}$ per year (Fig. $3 \mathrm{~d}$ ), close to the predicted long-term Afro-Arabian half-rate 8,27 . These results suggest that since $\sim 200 \mathrm{ka}$ volcanism in the main rift zone has been primarily focused along the axial graben, demonstrating long-term focused magmatic accretion. The long-term extension rate implied by our age-profile is consistent with the recent rifting activity observed here, which suggests that crustal deformation and extension along the incipient African-Arabian plate boundary occurs via discrete magmatic episodes, focused along the segment axis ${ }^{3,4}$. This model of segment growth is supported by geochemical data for these lavas (ref. 28 and S. Medynski, personal communication), which shows that lavas sampled from the axis outwards (shown in Fig. 4a) have a limited compositional range (Fig. 4c) and are distinct from those erupted at other nearby volcanoes (that is, the Dabbahu volcano and volcanic vents west of the main segment; 


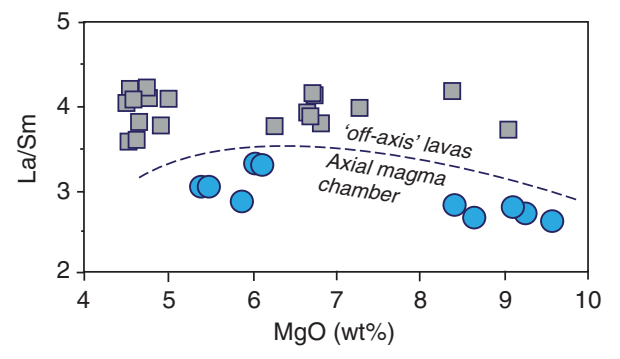

Figure 5 | La/Sm versus MgO for lavas from the DMH segment and nearby volcanoes. A clear compositional division exists between the lavas that form the main part of the segment (including recently erupted lavas) (blue symbols) and those from other nearby vents and volcanoes (grey symbols; that is, Badi and Dabbahu volcanoes; Fig. 2). Data from ref 28 and S. Medynski personal communication.

Fig. 2). Recent dyke intrusions have been principally fed by melts sourced from the mid-segment magma reservoir beneath the AVC and the compositional similarity between the recent fissural basalts and lavas sampled across the rift flanks (as shown in Figs $4 \mathrm{c}$ and 5) suggests that this centralized supply has been feeding axial intrusions over the last $\sim 200$ ka of segment growth.

The new age data presented here for lavas from the DMH rift zone indicate a systematic age-distance trend from the rift axis, consistent with a model of segment formation via focused axial dyke intrusion and volcanic accretion since at least $\sim 200 \mathrm{ka}$. The observed age-distribution across the rift flanks implies that during this period the long-term time-averaged opening rate at this rift zone has closely approximated the total estimated extension rate between Africa and Arabia and strain accommodation has, therefore, been focused here over this period. The composition of the lavas that form the surface of the main part of the segment is consistent with a common source to the recent fissural basalts ${ }^{18}$, and supports the existence of a long-lived centralized melt supply. Focused magmatic accretion in the crust can, therefore, remain stable over a kilo-year timescale before marked crustal thinning. Future work involving detailed structural investigations and further geochronological analysis will build upon the constraints presented to develop understanding of how this and other mature rift systems develop during the latter phases of continental break-up.

\footnotetext{
Methods

${ }^{40} \mathbf{A r}-{ }^{39} \mathrm{Ar}$ geochronology. Samples were first inspected in thin section to select those with textures that were as close to holocrystalline and equigranular as possible and to identify the appropriate size fraction required for a groundmass separate. Selected samples were then crushed and sieved to collect the desired size fraction. This was then thoroughly cleaned in an ultrasonic bath with successive rinses of DI water and isopropyl alcohol. After cleaning samples were passed through a FRANTZ magnetic separator to increase the proportion of groundmass to phenocryts. Around $250 \mathrm{mg}$ of groundmass material was then handpicked using a binocular microscope.

For irradiation, $\sim 250 \mathrm{mg}$ groundmass sample were packaged in $\mathrm{Cu}$ foil and placed in a cylindrical quartz vial, together with fluence monitors of known age and $\mathrm{K}$-glass, and fluorite to measure interfering isotopes from $\mathrm{K}$ and $\mathrm{Ca}$. The quartz vials were wrapped in $0.5 \mathrm{~mm}$-thick Cd foil to shield samples from thermal neutrons during irradiation. The samples were irradiated for one (IRR279) or two (IRR276) hours in the central thimble of the US Geological Survey TRIGA reactor in Denver, Colorado ${ }^{29}$. The reactor vessel was rotated continuously during irradiation to avoid lateral neutron flux gradients. Reactor constants determined for these irradiations were indistinguishable from recent irradiations, and a weighted mean of constants obtained over the past 5 years yields ${ }^{40} \mathrm{Ar}^{39}{ }^{3 \mathrm{Ar}_{\mathrm{K}}}=0.0010 \pm$ $0.0004,{ }^{39} \mathrm{Ar} /{ }^{37} \mathrm{Ar} \mathrm{Ca}=0.00071 \pm 0.00005$, and ${ }^{36} \mathrm{Ar}^{37}{ }^{37} \mathrm{Ar} \mathrm{Ca}=0.000281 \pm 0.000006$ TCR-2 sanidine from the Taylor Creek Rhyolite ${ }^{30}$ was used as a fluence monitor with an age of $27.87 \mathrm{Ma}$. This monitor is a secondary standard calibrated against the primary intra-laboratory standard, SB-3, that has an age of $162.9 \pm 0.9 \mathrm{Ma}$ (ref. 31). Fluence monitors were analysed using a continuous $\mathrm{CO} 2$ laser system and mass spectrometer described by ref. 32. Argon was extracted from groundmass and mica separates using a Mo crucible in a custom resistance furnace modified from
}

the design of ref. 33 attached to the above mass spectrometer. Heating temperatures were monitored with an optical fibre thermometer and controlled with an Accufiber Model 10 controller. Gas was purified continuously during extraction using two SAES ST-172 getters operated at $4 \mathrm{~A}$ and $0 \mathrm{~A}$.

Mass spectrometer discrimination and system blanks are important factors in the precision and accuracy of ${ }^{40} \mathrm{Ar} /{ }^{39} \mathrm{Ar}$ age determinations of Pleistocene lavas because of low-radiogenic yields. Discrimination is monitored by analysing splits of atmospheric Ar from a reservoir attached to the extraction line and for these samples D $1 \mathrm{amu}=1.007504 \pm 0.000279$. All isotopic ratios are mass discrimination corrected using ${ }^{40} \mathrm{Ar} /{ }^{36} \mathrm{Ar}=295.5$ (ref. 34). A recent determination of atmospheric argon $\left({ }^{40} \mathrm{Ar} /{ }^{36} \mathrm{Ar}=298.56 \pm 0.31\right.$; ref. 35$)$ is more precise, but acceptance is controversial and that ratio has no impact on this study because normalizing to a different value does not change the age ${ }^{36}$. Typical system blanks including mass spectrometer backgrounds were $1.5 \times 10^{-18} \mathrm{~mol}$ of $\mathrm{m} / \mathrm{z} 36,9 \times 10^{-17} \mathrm{~mol}$ of $\mathrm{m} / \mathrm{z}$ $37,3 \times 10^{-18} \mathrm{~mol}$ of $\mathrm{m} / \mathrm{z} 39$ and $1.5 \times 10^{-16} \mathrm{~mol}$ of $\mathrm{m} / \mathrm{z} 40$, where $\mathrm{m} / \mathrm{z}$ is mass/ charge ratio.

In the incremental-heating experiments, the extraction line is isolated from pumping systems and the sample is heated to a specified temperature for $10 \mathrm{~min}$ cooled for 3-5 min and transferred to an isolated mass spectrometer. The gas is exposed to getters during the entire extraction. Isotopic ratios are measured and corrected for instrumental blanks, mass discrimination and interfering isotopes generated in the reactor. In these experiments, we separated and loaded enough material to do 12-18 steps on each unknown in order to carefully characterize the argon release. The incremental-heating data are plotted both as an age spectrum diagram and as an isotope correlation (isochron) diagram. For the age spectrum, apparent ages are calculated assuming that non-radiogenic Ar is atmospheric $\left({ }^{40} \mathrm{Ar} /{ }^{36} \mathrm{Ar}=295.5\right)$ in composition and are plotted against the cumulative ${ }^{39} \mathrm{Ar}$ released during the experiment. In cases with several contiguous steps yielding ages within analytical error, we calculate and report plateau ages by weighing individual ages by the inverse of their analytical error. Most groundmass age experiments do not yield identical ages across the entire spectrum due to minor alteration, recoil of ${ }^{39} \mathrm{Ar}$ during irradiation or modest excess ${ }^{40} \mathrm{Ar}$. Generally accepted criteria for a meaningful incremental-heating age are; 1: well-defined plateau (horizontal age spectrum) for $>50 \%$ of the ${ }^{39} \mathrm{Ar}$ released; 2: well-defined isochron for the plateau gas fractions; 3: concordant plateau and isochron ages; and $4:{ }^{40} \mathrm{Ar} /{ }^{36} \mathrm{Ar}$ isochron intercept not significantly different from 295.5 (refs 37-39). For isochron plots, data are not corrected using an atmospheric ratio. Isochron ages include plateau steps on well-behaved samples or a subset of data that yield a reasonable goodness of fit. We show normal isochron plots for these low-radiogenic rocks because the data are easier to visualize. Inverse isochron results are indistinguishable. Isochron ratios are particularly vulnerable to mobilization of argon isotopes during irradiation ${ }^{24}$, particularly in fine-grained volcanic rocks. ${ }^{39} \mathrm{Ar}$ produced from ${ }^{39} \mathrm{~K}$ in the reactor recoils $\sim 0.1 \mu \mathrm{m}$ causing different degassing rates during analysis ${ }^{24}$. Recoil moves ratios along the $x$-axis of isotope correlation plots with low-T steps moved to lower values (loss of ${ }^{39} \mathrm{Ar}$ ) and high-T steps moved toward higher values (deeply implanted ${ }^{39} \mathrm{Ar}$ ). In this case, the isochron line becomes shallow, yielding a high ${ }^{40} \mathrm{Ar} /{ }^{36} \mathrm{Ar}$ ratio and young isochron age. We interpret this as an irradiation artifact. The most reliable results generally include gas from the middle of the release spectrum with consistent $\mathrm{K} / \mathrm{Ca}$ ratios and concordant isochron data with ${ }^{40} \mathrm{Ar} /{ }^{36} \mathrm{Ar}$ intercepts within error of air. Reported uncertainties on ages and isotopic ratios are $1 \sigma$. Final ages are recalculated to a $28.02 \mathrm{Ma}$ Fish Canyon sanidine age reflecting first principles calibration of GA1550 biotite at $98.8 \pm 1.0 \mathrm{Ma}$ (refs $39-41$ ).

\section{References}

1. Hayward, N. J. \& Ebinger, C. J. Variations in the along-axis segmentation of the Afar Rift system. Tectonics 15, 244-257 (1996).

2. Abdallah, A. et al. Relevance of Afar seismicity and volcanism to the mechanics of accreting plate boundaries. Nature 282, 17-23 (1979).

3. Ebinger, C. et al. Length and timescales of rift faulting and magma intrusion: the Afar Rifting Cycle from 2005 to present. Ann. Revs. Earth Planet Sci. 38, 439-466 (2010).

4. Wright, T. J. et al. Geophysical constraints on the dynamics of spreading centres from rifting episodes on land. Nature Geosci. 5, 242-250 (2012).

5. Perfit, M. R. \& Chadwick, Jr W. W. in Faulting and Magmatism at Mid-ocean Ridges. (eds Buck, R. W. et al.) 106, 59-116 (Geophysical Monograph Series, 1998).

6. Rowland, J. V. et al. Fault growth at a nascent slow spreading ridge: 2005 Dabbahu rifting episode, Afar. Geophys. J. Int. 171, 1226-1246 (2007).

7. Bastow, I. \& Keir, D. The protracted development of the continent-ocean transition in Afar. Nature Geosci. 4, 248-250 (2011).

8. McClusky, S. et al. Kinematics of the southern Red Sea-Afar Triple Junction and implications for plate dynamics. Geophys. Res. Lett. 37, L05031 (2010).

9. Barberi, F. \& Varet, J. Volcanism in Afar: small-scale plate tectonic implications. Geol. Soc. Am. Bull. 88, 1251-1266 (1977).

10. Bridges, D., Mickus, K., Gao, S., Abdelsalam, M. G. \& Alemu, A. Magnetic stripes of a transitional continental rift in Afar. Geology 40, 203-206 (2012). 
11. Ebinger, C. et al. Capturing magma intrusion and faulting processes during continental rupture: seismicity of the Dabbahu Afar rift. Geophys. J. Int. 174, 1138-1152 (2008).

12. Keir, D. et al. Evidence for focused magmatic accretion at segment centers from lateral dike injections captured beneath the Red Sea rift in Afar. Geology 37, 59-62 (2009).

13. Belachew, M. et al. Comparison of dike intrusion in an incipient seafloorspreading segment in Afar, Ethiopia: Seismicity perspectives. J. Geopys. Res. 116, B06405 ((2011).

14. Wright, T. J. et al. Magma-maintained rift segmentation at continental rupture in the 2005 Afar dyking episode. Nature 442, 291-294 (2006).

15. Hamling, I. J. et al. Geodetic observations of the ongoing Dabbahu rifting episode: new dyke intrusions in 2006 and 2007. Geophys. J. Int. 178, 989-1003 (2009).

16. Grandin, R. et al. September 2005 Manda Hararo-Dabbahu rifting event, Afar (Ethiopia): constraints provided by geodetic data. J. Geophys. Res. 114, B08404 (2009).

17. Grandin, R. et al. Sequence of rifting in Afar, Manda-Hararo rift, Ethiopia, 2005-2009: time-space evolution and interactions between dikes from interferometric synthetic aperture radar and static stress change modeling. J. Geophys. Res. 115, B10413 (2010).

18. Ferguson, D. J. et al. Recent rift-related volcanism in Afar, Ethiopia. Earth Planet Sci. Lett. 292, 409-418 (2010).

19. Sempere, J.-C., Lin, J., Brown, H. S., Schouten, H. \& Purdy, G. M. Segmentation and morphotectonic variations along a slow-spreading center: the Mid-Atlantic Ridge $24^{\circ}-30^{\circ} 40^{\prime}$ N. Mar. Geophys. Res. 15, 153-200 (1993).

20. Tulcholke, B. E. \& Lin, J. A geological model for the structure of ridge segments in slow-spreading ocean crust. J. Geophys. Res. 99, 11937-11958 (1994).

21. Bjornsson, A., Johnsen, G., Sigurdsson, S., Thorbergsson, G. \& Tryggvason, E. Rifting of a plate boundary in North Iceland 1975-1978. J. Geophys. Res. 84, 3029-3038 (1977).

22. Lahitte, P., Gillot, P.-Y., Kidane, T., Courtillot, V. \& Bekele, A. New age constraints on the timing of volcanism in central Afar, in the presence of propagating rifts. J. Geophys. Res. 108, 2123-2140 (2003).

23. Keir, D. et al. Mapping the evolving strain field during continental breakup from crustal anisotropy in the Afar Depression. Nat. Commun. 2, 285 (2011).

24. Huneke, J. C. \& Smith, S. P. The realities of recoil: ${ }^{39}$ Ar recoil out of small grains and anomalous patterns in ${ }^{39} \mathrm{Ar}^{40} \mathrm{Ar}$ dating. Geochim. Cosmochim. Ac. Suppl. 7 (Seventh Lunar Science Conference 1987-2008, 1976).

25. Field, L., Blundy, J., Calvert, A. \& Yirgu, G. Magmatic history of Dabbahu a composite volcano in the Afar Rift, Ethiopia. Geol. Soc. Am. Bull 125, 128-147 (2013).

26. Smith, D. K. \& Cann, J. R. Building the crust at the Mid-Atlantic Ridge. Nature 365, 707-715 (1993).

27. Vigny, C., Huchon, P., Ruegg, J.-C., Khanbari, K. \& Asfaw, L. M. 25 years of geodetic measurements along the Tadjura-Asal rift system, Djibouti East Africa.. J. Geophys. Res. 111, B02402 (2006).

28. Ferguson, D. J. Volcanic and Magmatic Processes at a Young Spreading Centre in Afar, Ethiopia. D.Phil Thesis (University of Oxford, 2011).

29. Dalrymple, G. B., Alexander, Jr E. C., Lanphere, M. A. \& Kraker, G. P. Irradiation of samples for ${ }^{40} \mathrm{Ar} /{ }^{39} \mathrm{Ar}$ dating using the Geological Survey TRIGA reactor. USGS Prof. Paper 1176 (1981).

30. Dalrymple, G. B. \& Duffield, W. A. High precision ${ }^{40} \mathrm{Ar} /{ }^{39} \mathrm{Ar}$ dating of Oligocene rhyolites from the Mogollon-Datil volcanic field using a continuous laser system. Geophys. Res. Lett. 15, 463-466 (1988).
31. Lanphere, M. A. \& Dalrymple, G. B. First-principles calibration of ${ }^{38}$ Ar tracers: implications for the ages of ${ }^{40} \mathrm{Ar} /{ }^{39} \mathrm{Ar}$ fluence standards. USGS. Prof. Paper 1621 (2000).

32. Dalrymple, G. B. The GLM continuous laser system for ${ }^{40} \mathrm{Ar} /{ }^{39} \mathrm{Ar}$ dating: description and performance characteristrics, in New Frontiers in Stable Isotopic Research; Laser Probes, Ion Probes, and Small-Sample Analysis: USGS Bull. (eds Shanks, W. C. III \& Criss, R. E.) 1890, 89-96 (1989).

33. Staudacher, T., Jessberger, E. K., Dorflinger, J. \& Kiko, J. A refined ultrahighvacuum furnace for rare gas analysis. J. Phys. E: Sci. Instrum. 11, 781-784 (1978).

34. Steiger, R. H. \& Jager, E. Sub-commission on geochronology: convention on the use of decay constants in geo- and cosmochronology. Earth Planet. Sci. Lett. 36, 359-362 (1977).

35. Lee, J. et al. A redetermination of the isotopic abundances of atmospheric Ar. Geochim. Cosmochim. Ac. 70, 4507-4512 (2006).

36. Renne, P. R., Cassata, W. S. \& Morgan, L. E. The isotopic composition of atmospheric argon and Ar/Ar geochronology: time for a change? Quat. Geochronol. 4, 288-298 (2009).

37. Fleck, R. J., Sutter, J. F. \& Elliot, D. H. Interpretation of discordant ${ }^{40} \mathrm{Ar} /{ }^{39} \mathrm{Ar}$ age-spectra of Mesozoic tholeiites from Antarctica. Geochim. Cosmochim. Ac. 41, 15-32 (1977).

38. Dalrymple, G. B. \& Lanphere, M. A. Potassium-Argon Dating-Principles, Techniques, and Applications to Geochronology (W.H. Freeman and Company, (1969).

39. Dalrymple, G. B. \& Lanphere, M. A. ${ }^{40} \mathrm{Ar} /{ }^{39} \mathrm{Ar}$ age spectra of some undisturbed terrestrial samples. Geochim. Cosmochim. Ac. 38, 715-738 (1974).

40. Renne, P. R. et al. Intercalibration of standards, absolute ages and uncertainties in ${ }^{40} \mathrm{Ar} /{ }^{39} \mathrm{Ar}$ dating. Chem. Geol. 145, 117-152 (1998).

41. McDougall, I. \& Wellman, P. Calibration of GA1550 biotite standard for K/Ar and ${ }^{40} \mathrm{Ar} /{ }^{39} \mathrm{Ar}$ dating. Chem. Geol. 280, 19-25 (2011).

\section{Acknowledgements}

We are grateful to various members of the Afar Rift Consortium (www.see.leeds.ac.uk/ afar), particularly B. Hoffman, T. Barnie, J. Rowland and R. Pik. This work was supported by a NERC consortium grant (NE/E006469/1).

\section{Author contributions}

Project planning and fieldwork in Afar was completed by D.J.F., D.M.P., J.D.B., G.Y. and T.J.W. Sample preparation and geochronological analysis was performed by D.J.F. and A.T.C. All authors discussed the results and interpretation. D.J.F. wrote the paper with input from all others.

\section{Additional information}

Supplementary Information accompanies this paper at http://www.nature.com/ naturecommunications

Competing financial interests: The authors declare no competing financial interests

Reprints and permission information is available online at http://npg.nature.com/ reprintsandpermissions/

How to cite this article: Ferguson, D. J. et al. Constraining timescales of focused magmatic accretion and extension in the Afar crust using lava geochronology. Nat. Commun. 4:1416 doi: 10.1038/ncomms2410 (2013). 